\title{
Downregulation of the Central Noradrenergic System by Toxoplasma gondii Infection
}

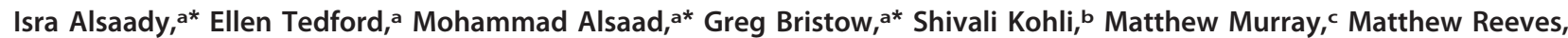 \\ M. S. Vijayabaskar, ${ }^{\text {d* Steven J. Clapcote, }}{ }^{\text {b Jonathan Wastling, }}{ }^{\text {e }}$ (D) Glenn A. McConkey ${ }^{\mathrm{a}}$ \\ aSchool of Biology, Faculty of Biological Sciences, University of Leeds, Leeds, United Kingdom \\ bSchool of Biomedical Sciences, Faculty of Biological Sciences, University of Leeds, Leeds, United Kingdom \\ Institute of Immunity \& Transplantation, UCL Department of Virology, Division of Infection \& Immunity, Royal Free Hospital, London, United Kingdom \\ dSchool of Molecular and Cellular Biology, Faculty of Biological Sciences, University of Leeds, Leeds, United Kingdom \\ eFaculty of Natural Sciences, University of Keele, Newcastle-under-Lyme, United Kingdom
}

ABSTRACT Toxoplasma gondii is associated with physiological effects in the host. Dysregulation of catecholamines in the central nervous system has previously been observed in chronically infected animals. In the study described here, the noradrenergic system was found to be suppressed with decreased levels of norepinephrine (NE) in brains of infected animals and in infected human and rat neural cells in vitro. The mechanism responsible for the NE suppression was found to be downregulation of dopamine $\beta$-hydroxylase (DBH) gene expression, encoding the enzyme that synthesizes norepinephrine from dopamine, with downregulation observed in vitro and in infected brain tissue, particularly in the dorsal locus coeruleus/pons region. The downregulation was sex specific, with males expressing reduced DBH mRNA levels whereas females were unchanged. Rather, DBH expression correlated with estrogen receptor in the female rat brains for this estrogen-regulated gene. DBH silencing was not a general response of neurons to infection, as human cytomegalovirus did not downregulate DBH expression. The noradrenergic-linked behaviors of sociability and arousal were altered in chronically infected animals, with a high correlation between DBH expression and infection intensity. A decrease in DBH expression in noradrenergic neurons can elevate dopamine levels, which provides a possible explanation for mixed observations of changes in this neurotransmitter with infection. Decreased NE is consistent with the loss of coordination and motor impairments associated with toxoplasmosis. Further, the altered norepinephrine synthesis observed here may, in part, explain behavioral effects of infection and associations with mental illness.

KEYWORDS norepinephrine, apicomplexan parasites, behavior, bradyzoite, hostpathogen interactions, intracellular parasites, protozoa

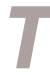
oxoplasma gondii infects warm-blooded animals and is characterized by a transient acute infection, wherein vegetative tachyzoite forms rapidly replicate in tissues, followed by conversion of some tachyzoites to slowly replicating bradyzoites, generating a persistent chronic infection. Chronic infection can persist for years and potentially the lifetime of the host, with the bradyzoite-stage parasites encysted in cells within immunoprivileged tissues, including muscle, eyes, and neurons in the brain. Several reports have published host behavioral changes with infection. A selective loss of aversion to feline urine and increased motor activity has been observed in rodents, specifically manipulating behavior that will enhance the probability of parasite transmission $(1,2)$.

Toxoplasmosis can be a severe disease in immunocompromised individuals and in utero. Infection can cause retinochoroiditis and congenital hydrocephalus and cerebral

Citation Alsaady I, Tedford E, Alsaad M, Bristow G, Kohli S, Murray M, Reeves M, Vijayabaskar MS, Clapcote SJ, Wastling J, McConkey GA. 2019. Downregulation of the central noradrenergic system by Toxoplasma gondii infection. Infect Immun 87:e00789-18. https:// doi.org/10.1128/IAl.00789-18.

Editor John H. Adams, University of South Florida

Copyright $\odot 2019$ American Society for Microbiology. All Rights Reserved.

Address correspondence to Glenn A. McConkey, G.A.McConkey@Leeds.ac.uk.

* Present address: Isra Alsaady, Faculty of Applied Medical Science, University of King Abdulaziz, Jeddah, Saudi Arabia; Mohammad Alsaad, Center for Neglected Tropical Diseases, National Health Laboratory, Saudi Ministry of Health, Riyadh, Saudi Arabia; Greg Bristow, Division of Biomedical and Life Sciences, Furness College, University of Lancaster, Lancaster, United Kingdom; M. S. Vijayabaskar, Wellcome Trust Sanger Institute, Hinxton, Cambridge, United Kingdom.

I.A. and E.T. contributed equally to this study.

Received 22 October 2018

Accepted 15 November 2018

Accepted manuscript posted online 3

December 2018

Published 14 January 2019 
calcifications. T. gondii was recently ranked the second most important foodborne parasite in Europe, and toxoplasmosis is classified by the Centers for Disease Control and Protection as a neglected parasitic infection (3). It has also been linked by epidemiological studies to cognitive impairment and major mental illnesses. Severe cases are associated with psychoses, seizures, and loss of coordination. However, there are no available cures for infection. Sensorimotor defects, tremors, and headshaking have also been observed in chronically infected mice $(4,5)$.

In the brain, encysted bradyzoite-stage parasites are restricted to neurons, and recent work has found that neurons are the primary target cell for $T$. gondii during central nervous system (CNS) infection $(6,7)$. Recently, a large omics study found canonical pathways in movement disorders, epilepsy, cancer, and Alzheimer's disease associated with altered gene expression in neural stem cells expressing a mixture of astrocyte and neuronal markers after $18 \mathrm{~h}$ of tachyzoite infection (8). As chronic infection is restricted to neurons in the CNS, this study investigated changes in gene expression in neuron-like cells that express neurotransmitters and can form synapses.

Early studies found changes in dopaminergic neurotransmission associated with infection, with high levels of dopamine (DA) in brain tissue cysts of chronically infected rodents and abrogation of infection-induced behavior changes when animals were treated with the dopamine antagonists haloperidol and GBR-12909 (9-11). Perturbations in catecholaminergic signaling with chronic infection have been observed, with elevated DA metabolites in the cortex and decreased norepinephrine (NE) in the cortex and amygdala and loss of amphetamine-induced locomotor activity $(12,13)$. There are discrepancies in observations of changes in dopamine levels in the brain with $T$. gondii infection (14-18). Increased levels of dopamine in infected cells have been found when catecholaminergic cells are maintained at a physiological pH (19). Hence, in this study we examined changes in catecholamine expression with infection and explored the underlying alterations in gene expression as a biological mechanism to explain observed changes in NE and DA neurotransmission during CNS infection.

\section{RESULTS}

Norepinephrine regulation in the brain during $T$. gondii infection. Initially, the effect of chronic infection on CNS NE and DA levels in the brains of T. gondii-infected animals was monitored. The level of NE was significantly decreased in infected animals $(P=0.0019)$, with a reduction of $50 \% \pm 14 \%$ in the brains (Fig. $1 \mathrm{~A})$. This experiment and those that follow were performed with the Prugniaud strain unless otherwise stated. Decreased NE in T. gondii-infected mice has been observed in other studies $(12,14)$. The suppression observed with infection (Fig. 1A) is analogous to decreases in CNS NE levels observed with high-affinity DBH inhibitors (20). High doses of disulfiram and nepicastat, which have been used clinically, reduce brain NE levels by $36 \%$ to $45 \%(21,22)$. Although the level of NE was reduced with infection, the rats displayed no obvious signs of pathology. Rats with chronic T. gondii infections do not usually exhibit symptoms of illness (23). The median level of DA in the brains of infected rats was increased to double the uninfected level in this cohort, but this change was not statistically significant ( $P=0.12$ ) (Fig. 1B). These observations fit with other investigations, in which high DA levels were observed in cysts but brain tissue levels of DA were unchanged $(16,19,24)$.

To assess whether the change in level of NE could also be observed during in vitro infection, we performed infections with catecholaminergic cells. PC12 cells, derived from a pheochromocytoma of the rat adrenal medulla, are fully functional in synthesis and packaging of DA and NE for vesicle-mediated release upon stimulation, form dendritic extensions, and express dopamine receptors as a classic cell line model of catecholaminergic neurons. We shocked Pruniaud tachyzoites with high $\mathrm{pH}$ to induce bradyzoite development prior to infection of cells, as in previous studies $(9,19)$. As catecholamine synthesis by $\mathrm{PC} 12$ cells is sensitive to $\mathrm{pH}$, this technique was used to maintain the full catecholamine biosynthetic capacity of the cells $(25,26)$. 
A

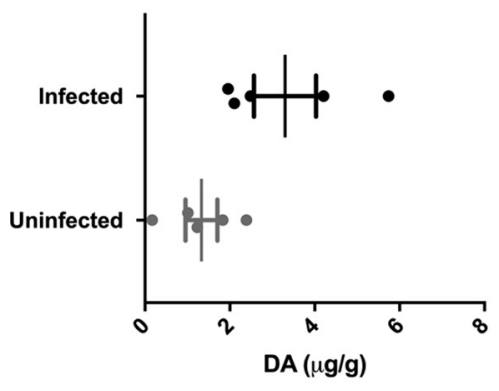

C

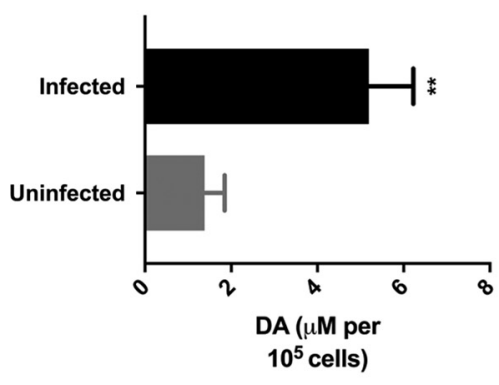

B

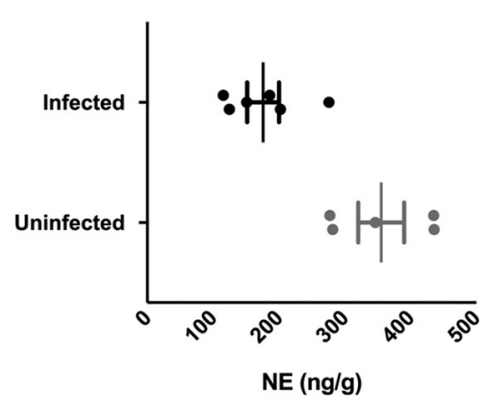

D

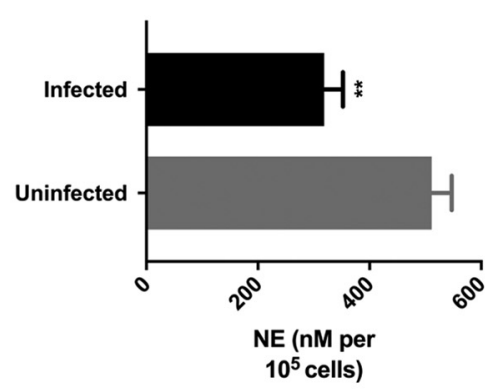

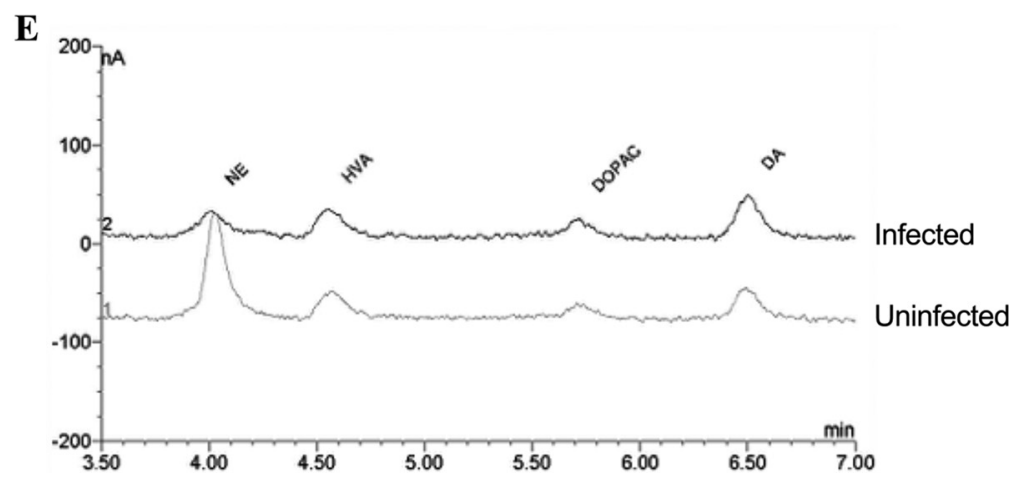

FIG 1 Catecholamine levels with T. gondii infection in the brain and catecholaminergic cells. (A) A graph of the norepinephrine concentration in the brains of uninfected and infected rats, with each point representing one animal and bars showing the means \pm SEM $(P=0.0019$, Student's $t$ test; $n=6$ infected and 6 mock-infected animals). (B) Dopamine levels in the brains of the same uninfected and infected rats shown graphically ( $P=0.12$, Student's $t$ test). (C) Norepinephrine levels in uninfected and infected catecholaminergic PC12 cells at day 5 of infection $(P=0.0024, n=3$ biological replicates). (D) Levels of dopamine in the same infected PC12 cells, plotted as described for panel B. $P=0.0043, n=3$ biological replicates with triplicate readings. (E) Overlay of chromatograms from HPLC-ED of uninfected and infected PC12 cells.

NE and DA levels were measured in PC12 cells 5 days after parasite infection. NE levels were decreased in infected cultures to $62 \% \pm 6.1 \%(P=0.0024)$ of the uninfected cell level (Fig. $1 C$ and E). The reduction in NE cannot be due to cell lysis, as values are expressed relative to cell number. DA levels in infected PC12 cells were greater than those in uninfected cells $(P=0.0043)$ in the same samples that exhibited suppression of NE (Fig. 1D). The 3.8- \pm 0.74 -fold increase is similar to that found in our previously published work with infected PC12 cells $(9,19)$. In vitro infection of catecholamineproducing cells reduced NE while elevating dopamine levels.

Regulation of the levels of NE and DA may be due to changes in synthesis, transport and storage, or degradation. Further, the mechanism(s) responsible for the opposing decrease in NE and increase in DA in catecholaminergic cells was unclear from these observations. Therefore, we examined the effects of the parasite on proteins expressed by the host neuronal cells. 
Downregulation of a key enzyme for norepinephrine synthesis during infection. The biological mechanism(s) responsible for the decreased NE with infection was investigated. Preliminary experiments with a genome scan of infected rat catecholaminergic cells for gene expression levels identified that the most significantly altered expression was downregulation of the dopamine $\beta$-hydroxylase (DBH) gene $\left(P=7.2 \times 10^{-13}\right)$ (data not shown). Although the results were preliminary, rat housekeeping gene expression (glyceraldehyde-3-phosphate dehydrogenase [GAPDH], ribosomal proteins, tRNA ligases, and tubulin) was unchanged, while T. gondii bradyzoite genes (BAG1, LDH2, and MAG1) were upregulated (see Table S1 in the supplemental material). We validated our preliminary data from the transcriptome scan with reverse transcription-quantitative PCR (RT-qPCR) of a collection of catecholamine biosynthesis and metabolism genes. The norepinephrine biosynthetic pathway is shown in Fig. $2 \mathrm{~A}$. The only gene altered in expression in this set was downregulation of DBH (Fig. 2B). Although expression of the phenylalanine hydroxylase gene (PAH) appears reduced, this reduction was not significant $(P=0.06)$. Levels of mRNA for tyrosine hydroxylase, dopamine decarboxylase, monoamine oxidase $A$, and dopamine receptors D1 and D2 were unchanged with infection. The lack of change in rat tyrosine hydroxylase and dopamine decarboxylase gene expression with $T$. gondii infection corresponds with previously published data (9). Hence, DBH expression was specifically downregulated in infected cells. This might not have been identified in transcriptomic studies published of whole infected brain tissue, which principally identified changes in expression of host immune response genes with the mixture of cell types in the brain $(27,28)$. A recent transcriptomic study by $\mathrm{Ngô}$ et al. (73) identified differentially expressed genes after only $18 \mathrm{~h}$ of infection (i.e., during vegetative replication stages) in neural stem cells that expressed a range of markers for structural proteins found among different types of neurons and astrocytes. Hence, those results are difficult to compare with our approach using neuronal cells that are fully functional in synthesis and release (with potassium activation) of DA and NE to investigate changes in expression of neuronal genes.

The change in DBH mRNA levels was observed over a time course of infection. Parasites were shocked with alkaline conditions in these (as described in Materials and Methods) and the above-described experiments to trigger bradyzoite differentiation. $\mathrm{DBH}$ gene expression decreased after 3 days of infection and further after 5 days in PC12 cells (30- \pm 2 -fold) relative to rat GAPDH $(P=0.0046)$ (Fig. 2 C). Microscopic analysis verified the maintenance of cell numbers and viability during the time course experiments. The level of DBH mRNA in uninfected PC12 cells was unchanged over the course of the experiment ( $P=0.58$ by one-way analysis of variance [ANOVA]).

To examine whether the silencing of $\mathrm{DBH}$ expression is a general response to $T$. gondii infection, we investigated the effect of infection on a human neuronal cell line. The BE(2)-M17 cell line was derived from a human neuroblastoma and possesses catecholaminergic properties and neuritic processes. These cells were infected with Prugniaud strain T. gondii in a fashion similar to that for the PC12 cells, and samples were taken after 3 and 5 days of infection. Expression of the DBH gene was downregulated $5.7- \pm 1.1$-fold by day 3 of infection $(P=0.00032)$ and $17- \pm 1.4$-fold by day 5 of infection ( $P=0.0010$ ) (Fig. 2D) relative to a housekeeping gene. $\mathrm{DBH}$ levels were consistent in uninfected $\mathrm{BE}(2)-\mathrm{M} 17$ cells throughout the experiment $(P=0.97$ by one-way ANOVA). We also found downregulation of $\mathrm{DBH}$ in $\mathrm{BE}(2)-\mathrm{M} 17$ cells infected with the T. gondii ME49 strain (Fig. S1).

$\mathrm{DBH}$ is the key link between NE and DA, as DBH metabolizes DA into NE. Decreased $\mathrm{DBH}$ will decrease synthesis of NE and simultaneously increase levels of the precursor DA. Suppression of DBH by downregulated expression of its gene provides a mechanistic explanation for the observed increase in DA in infected PC12 cells described above (Fig. 1C and D), coincident with decreased levels of NE. DA was not significantly increased in infected rat brains (Fig. 1B), as might have been expected with the disproportionately smaller number of noradrenergic than dopaminergic neurons. 
A<smiles>N[C@@H](Cc1ccc(O)cc1)C(=O)O</smiles><smiles>N[C@@H](Cc1ccc(O)c(O)c1)C(=O)[O-]</smiles>

L-3,4-dihydroxyphenylalanine<smiles>NCCc1ccc(O)c(O)c1</smiles>

Dopamine<smiles>[NH3+]CC(O)c1ccc(O)c(O)c1</smiles>

B

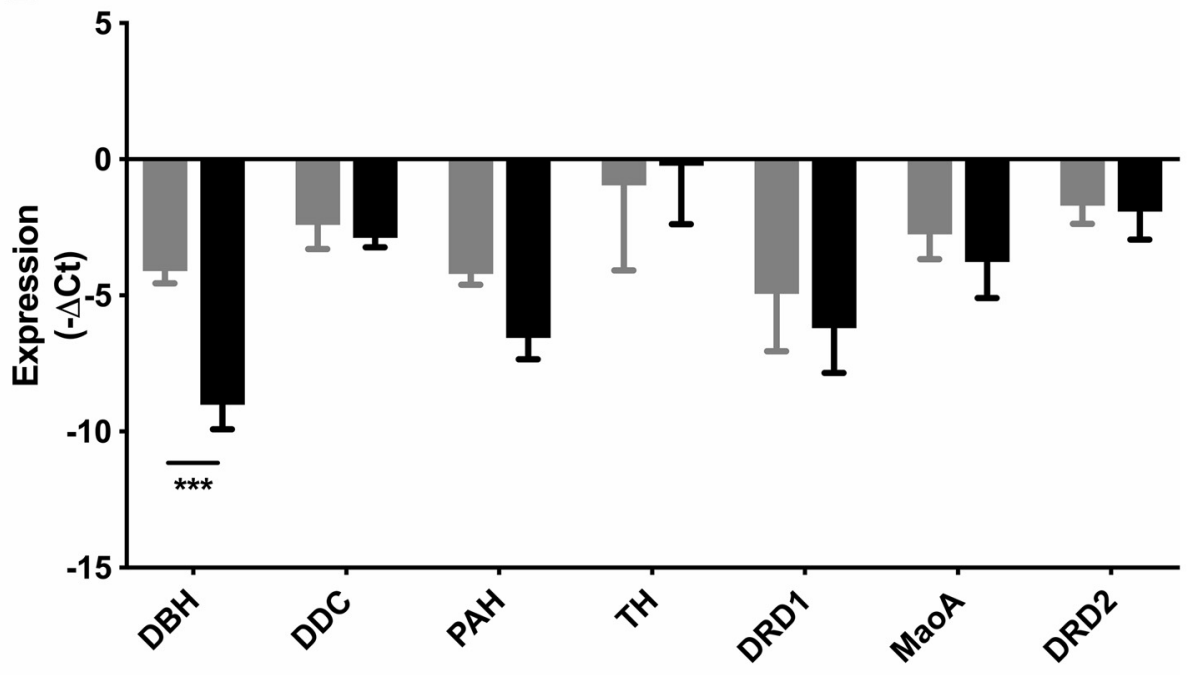

Norepinephrine
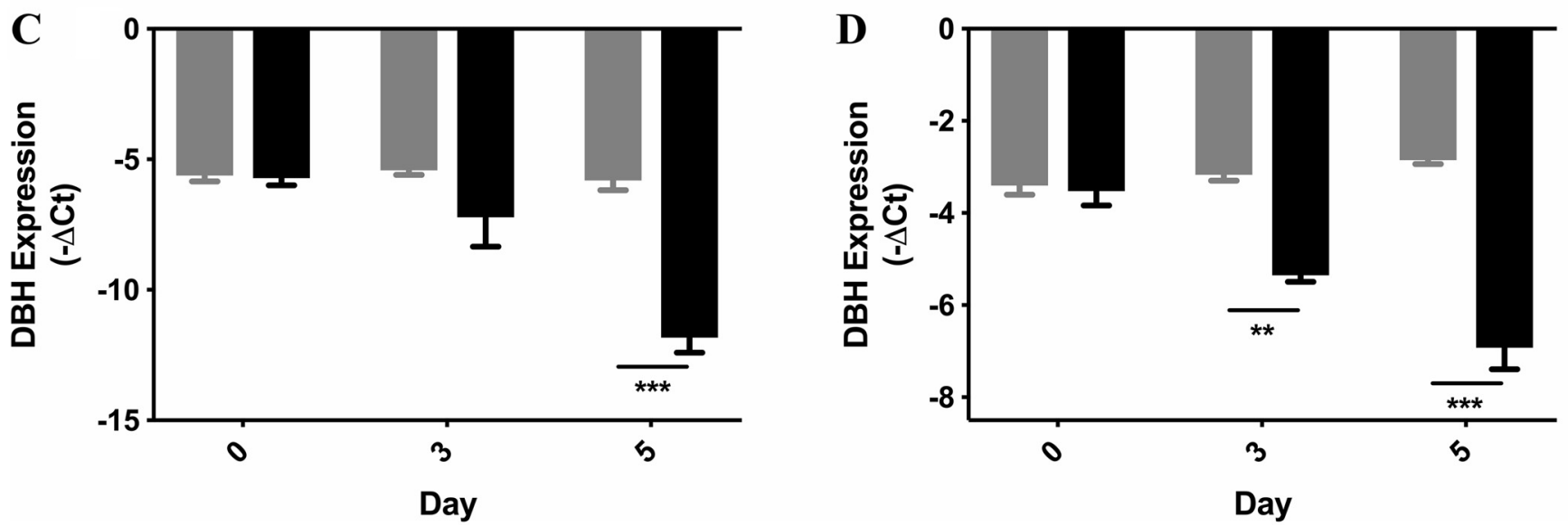

FIG 2 Norepinephrine biosynthesis in catecholaminergic cells with T. gondii infection. (A) Dopamine and norepinephrine biosynthetic pathway showing synthesis from tyrosine. DBH, dopamine $\beta$-hydroxylase; AADC, aromatic amino acid decarboxylase (also DDC); TH, tyrosine hydroxylase. Reactions in which dopamine and/or norepinephrine are bound (e.g., dopamine receptor D1 [DRD1], dopamine receptor D2 [DRD2]) or degraded (e.g., monoamine oxidase A $[\mathrm{MaoA}]$ ) are not included in this schematic. (B) Expression of the set of catecholaminergic genes during infection (black) or without infection (gray). Only DBH gene expression was significantly altered by infection ( $n=3$ biological replicates with triplicate readings; $\left.{ }^{* *}, P=0.008\right)$. PAH, phenylalanine hydroxylase. Error bars are \pm SEM. (C) Dopamine $\beta$-hydroxylase mRNA levels during a time course of infection (black) relative to levels for uninfected (gray) PC12 catecholaminergic cells and a rat housekeeping gene. ${ }^{* *}, P=0.0046, n=3$ biological replicates. (D) Plot of the level of DBH mRNA in human BE(2)-M17 neuronal cells over a time course of infection relative to human $\mathrm{GAPDH}$, showing that $T$. gondii induces $\mathrm{DBH}$ downregulation in rat and human neuronal cells. ${ }^{* *}, P=0.0010 ;{ }^{* * *}$, $P=0.00032 ; n=3$ biological replicates.

Dopamine $\beta$-hydroxylase expression is downregulated in the brain with infection. We examined whether the downregulation of DBH gene expression in neuronal cells was detectable during in vivo infection. DBH mRNA was quantified in the brains of chronically infected male rats. Gene expression was downregulated in infected animals by a median of $32 \pm 2.1$-fold relative to uninfected animals (Fig. 3A) $(P=0.0023)$. We examined the relationship between the intensity of brain 
A

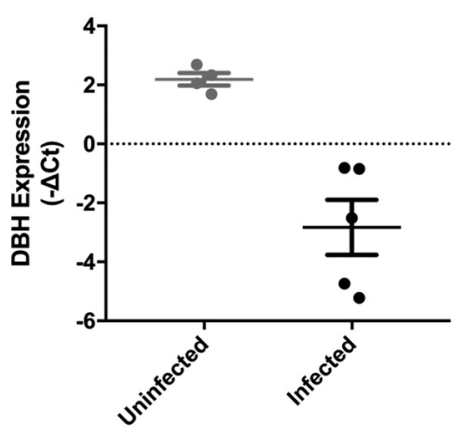

C

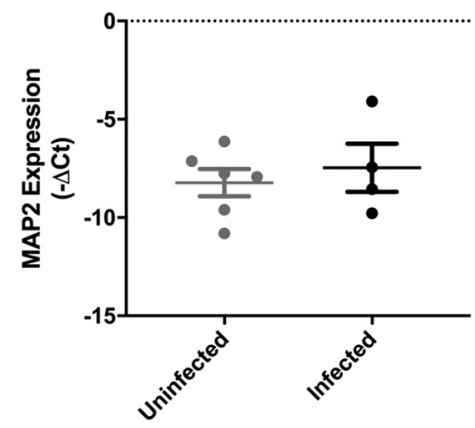

B

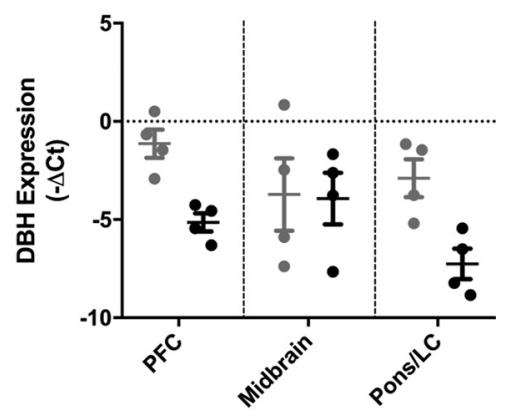

FIG 3 Infection downregulates dopamine $\beta$-hydroxylase gene expression in the brain. (A) DBH gene expression in the brains of uninfected (gray) and chronically infected (black) male rats plotted relative to GAPDH ( $P=0.0023 ; n=4$ uninfected and 5 infected animals). (B) Brain region-specific DBH gene expression in uninfected and infected rats in the prefrontal cortex (PFC) $(P=0.0034)$, midbrain, and pons/locus coeruleus (LC) $(P=0.012)$. Error bars are \pm SEM. $n=4$ uninfected and infected animals. (C) Plot showing expression of the neuronal MAP2 gene (as a percentage of GAPDH) in uninfected (gray) and chronically infected (black) brains for the animals shown in panel A $(P=0.57)$.

infection and DBH expression. A strong negative correlation was observed in infected animals between DBH mRNA and cyst density (tissue cysts can contain thousands of bradyzoites), with a correlation coefficient of -0.90 (Table 1). The coefficient of determination $\left(R^{2}\right)$ of 0.82 is a good fit for the linear regression.

TABLE 1 Sex-specific effect of chronic T. gondii infection on DBH levels ${ }^{a}$

\begin{tabular}{|c|c|c|c|c|}
\hline Status & Gender & $\mathrm{DBH}(\Delta \Delta C T)$ & $\operatorname{ESR}(\Delta \Delta C T)$ & $\begin{array}{l}P \text { value for } \mathrm{DBH} \\
\text { (uninfected versus infected) } \\
\text { and correlation coefficient }(r)\end{array}$ \\
\hline Uninfected & $M$ & -1 & NA & $P=0.0023$ and $r=0.91$ for \\
\hline Uninfected & M & -0.5 & NA & DBH and cyst number \\
\hline Uninfected & $\mathrm{M}$ & -0.72 & NA & \\
\hline Uninfected & $\mathrm{M}$ & -0.14 & NA & \\
\hline Infected & M & -7.4 & $\mathrm{NA}$ & \\
\hline Infected & $M$ & -4.7 & NA & \\
\hline Infected & M & -3 & NA & \\
\hline Infected & $M$ & -3 & NA & \\
\hline Infected & $M$ & -7.2 & NA & \\
\hline Uninfected & $\mathrm{F}$ & 3.6 & 3 & $P=0.45$ and $r=0.17$ for $\mathrm{DBH}$ \\
\hline Uninfected & $\mathrm{F}$ & -5.6 & -1.5 & and cyst number; $r=0.86$ \\
\hline Uninfected & $\mathrm{F}$ & 1.9 & -1.4 & for $\mathrm{DBH}$ and ESR \\
\hline Infected & $\mathrm{F}$ & 3.8 & 0.35 & \\
\hline Infected & $\mathrm{F}$ & -2.7 & 0.13 & \\
\hline Infected & $\mathrm{F}$ & -1.7 & -3.2 & \\
\hline Infected & $\mathrm{F}$ & -1.6 & -0.35 & \\
\hline Infected & $\mathrm{F}$ & -13 & -10 & \\
\hline
\end{tabular}

${ }^{a} \mathrm{M}$, male; F, female; NA, not applicable; $C_{T}$, threshold cycle. 
A
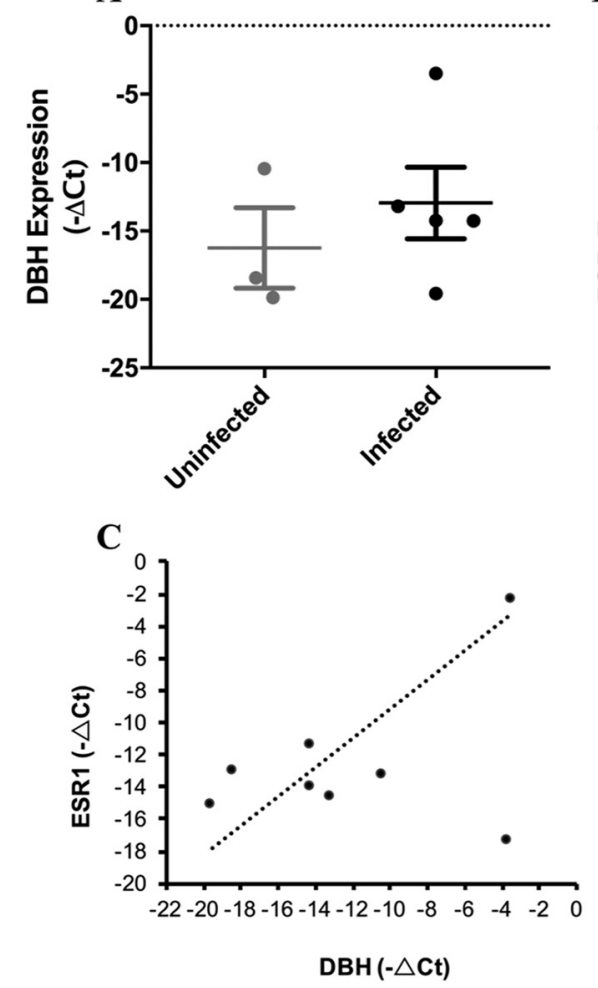

B

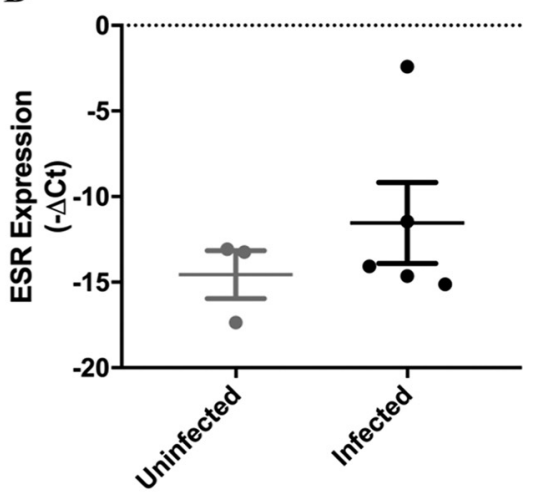

FIG 4 Dopamine $\beta$-hydroxylase expression was not suppressed in infected females. (A) Plot of DBH mRNA in the brains of uninfected (gray) and chronically infected (black) female rats ( \pm SEM; $n=3$ uninfected and 5 infected animals; $P=0.45$ ). (B) Expression of estradiol receptor 1 (ESR1) gene in brains of the same female rats shown graphically ( \pm SEM; $P=0.40$ ). (C) Correlation of DBH versus ESR1 gene expression in the brains (Pearson's correlation coefficient, 0.86).

DBH is expressed in noradrenergic neurons in the CNS, principally in the locus coeruleus (LC), with efferents extending to most brain regions. Therefore, we examined DBH gene expression in different brain regions in infected animals. DBH mRNA levels were lower ( $P$ values of 0.0034 and 0.012 , respectively) in the frontal lobe (prefrontal cortex; PFC) and the dorsal region (containing the LC, cerebellum, pons, and surrounding tissue) in infected animals. DBH expression was unchanged in the midbrain region containing the hippocampus, thalamus, and hypothalamus $(P=0.93)$ (Fig. 3B). Hence, the posterior area and the PFC had 2.5-fold and 4.5-fold, respectively, lower DBH mRNA in infected rats.

One plausible alternative explanation for the decrease in NE in the infected rat brains is poor neuronal health or neuronal death. T. gondii can lyse neurons, and synaptic loss and neuronal dysfunction have been observed in infected mice (29). In this study, we found no difference in neurons between infected and uninfected rats based on quantification of a neuron-specific mRNA, that encoding microtubuleassociated protein 2 (MAP2) (Fig. 3C) $(P=0.57)$.

Effect of sex on altered norepinephrine regulation with infection. An intriguing observation during these studies was the finding that females did not exhibit the downregulation of DBH. We noted a large range of DBH mRNA levels in the brains of female animals as an anomaly that could mask an effect of infection. Indeed, infected females did not exhibit a measurably lower level of DBH $(P=0.45)$ (Fig. $4 \mathrm{~A})$, with infected females possessing higher and lower DBH mRNA levels than vehicle controls (Table 1). A similar finding was observed with infected mice in which CNS levels of DBH mRNA in males were significantly downregulated $(P=0.0032, n=26)$, whereas the levels were unchanged in females ( $P=0.85, n=16$ ) (Fig. S2).

We investigated the reasons for this difference. $\mathrm{DBH}$ gene expression is regulated by estrogen, with the estrogen receptor binding to ER-response elements (ERE) at the $5^{\prime}$ 
A

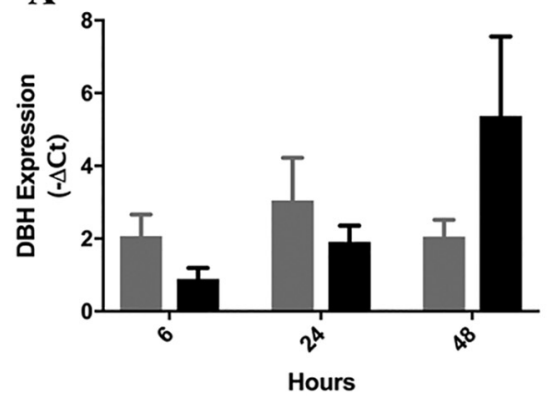

C

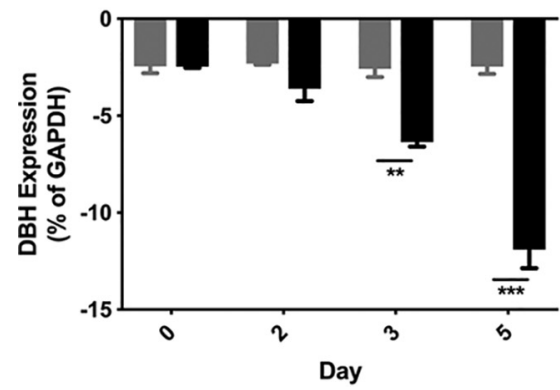

B

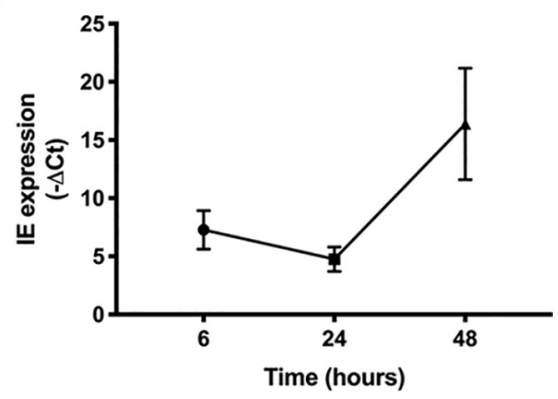

D

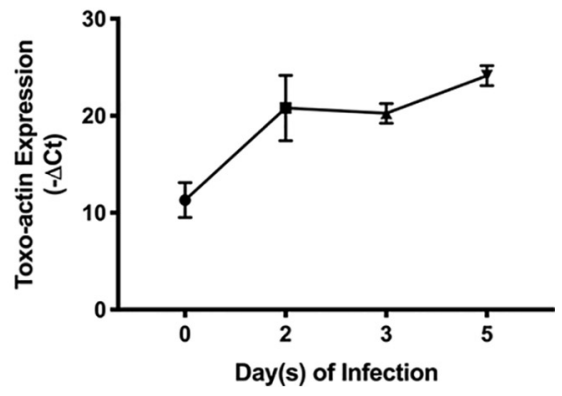

FIG 5 Dopamine $\beta$-hydroxylase suppression is pathogen specific. (A) Plot of DBH gene expression over a time course of $48 \mathrm{~h}$. Uninfected (gray) and human cytomegalovirus-infected (black) human BE(2)-M17 neuronal cell line, shown as a percentage of the housekeeping gene; $n=2$ biological repeats of triplicate measures. (B) Accumulation of HCMV UL123 IE as percent gene expression (normalized to GAPDH) over a time course. (C) Plot shows DBH expression over a similar time course for uninfected (gray) and $T$. gondii-infected (black) human neuronal cells as a percentage of the housekeeping gene. ${ }^{* *}, P=0.0015 ;{ }^{* * *}$, $P=0.0012 ; n=3$ biological repeats with triplicate measures; error bars indicate SEM. (D) The intensity of $T$. gondii infection over the time course based on levels of $T$. gondii actin plotted as a percentage of host GAPDH.

flanking region of the $\mathrm{DBH}$ gene and activating transcription $(30,31)$. Estrogen, estrogen receptor, and DBH mRNA levels fluctuate during the estrous cycle (32). Hence, we measured the levels of estrogen receptor 1 (ESR1) mRNA in the brains of the female rats used in this study.

A range of ESR1 levels was observed in the brains of the female rats, indicative of differences in their estrous cycle (Table 1). Expression of ESR1 was not altered by infection (Fig. 4B) $(P=0.40)$. ESR1 mRNA levels, however, strongly correlated with DBH mRNA (Fig. 4C), with a correlation coefficient of $0.86(P=0.0064)$, as expected (32). Together, the findings show that DBH expression correlated with ESR1 expression but not infection in females.

These findings provide a biological basis for previously observed sex-specific differences in the effect of $T$. gondii infection on mouse behavior and estrous dependence of aversive behaviors in female rats $(33,34)$.

Dopamine $\boldsymbol{\beta}$-hydroxylase expression in cytomegalovirus-infected human neuronal cells. To test whether DBH downregulation is a general response to chronic CNS infection or whether it is specific to T. gondii, changes in DBH gene expression in human neuronal cells infected with human cytomegalovirus (HCMV) were measured. DBH mRNA levels were not significantly changed over a time course of HCMV infection in BE(2)-M17 cells ( $P>0.13)$, with a trend for increased expression at $48 \mathrm{~h}$ (Fig. 5A). At this point, HCMV is entering the late stages of viral replication (as indicated by the immediate-early [IE] UL123 gene expression shown in Fig. 5B), yet the data clearly show HCMV infection does not decrease DBH expression. In comparison, DBH gene expression was downregulated (relative to the control gene) in the same cells infected with T. gondii, with DBH expression decreasing over the time course of the experiment (Fig. 5C) and experiencing a small increase in T. gondii (Fig. 5D). Hence, DBH downregulation is specific for $T$. gondii infection. 
Suppressed dopamine $\boldsymbol{\beta}$-hydroxylase alters norepinephrine-linked behaviors. A decrease in CNS NE, as observed with T. gondii infection (Fig. 1A), may have specific effects on behavior. Arousal and sociability are associated with CNS noradrenergic signaling $(35,36)$. Rodents with NE deficiency exhibit lower arousal and increased sociability.

Arousal is measured as a response to evoked or elicited activity and has been quantified in rodents by locomotion in a novel environment, such as an open field, at early time points in the experiment (37). Locomotion was recorded over 1-min intervals for the initial 5 min for chronically infected and uninfected mice in an open field apparatus and then over 5 -min intervals to $15 \mathrm{~min}$. The mice were individually removed from the home cage, placed in the center of the open field, and allowed to settle for $60 \mathrm{~s}(0$ to $60 \mathrm{~s}$ ), while the experimenter withdrew from the apparatus before readings were taken. T. gondii-infected mice exhibited decreased locomotor activity in the open field at early time points but not at later times (Fig. 6). The distance travelled by uninfected mice was one-and-a-half times that of infected animals in the 60- to 120-s $(P<0.0001)$ and 120 - to 180 -s $(P<0.0015)$ intervals. Representative tracking of uninfected and control mice illustrates the decreased locomotor activity during early time points (Fig. 6C). Additionally, the tracking shown illustrates the loss of fear of open spaces found in prior studies of $T$. gondii-infected rodents (38). In contrast to data for early time points, infected and control groups showed similar levels of activity in the open field after $180 \mathrm{~s}$. In the 5-min intervals between 5 and $15 \mathrm{~min}$, ambulation was not different, matching prior studies of locomotion in T. gondii-infected rodents monitored over longer periods (circa $30 \mathrm{~min}$ ) (38-40). Changes in initial behavioral response or arousal would not have been observed in these earlier studies that did report mobility in 1-min intervals. The DBH mRNA levels in the mice exhibited a correlation with early locomotor activity (Fig. S3). Published studies of $\mathrm{Dbh}^{-1-}$ knockout mice have described attenuated arousal and decreased locomotion, similar to that observed here, in ambulation in an open field at early time points $(35,36)$.

Cerebral NE levels have been associated with social interest and male aggression (22). Aggressive behavior is decreased and social memory altered in $\mathrm{Dbh}^{-1-}$ knockout mice (35). In this study, the three-chambered social approach test was used to measure sociability in uninfected and T. gondii-infected mice. This test is a well-established, sensitive model for measuring social interactions in mouse models of autism (41). In the first phase of the social approach test, which measures sociability, preference for exploring a cylinder containing an unfamiliar mouse rather than an empty cylinder was measured (42). Chronically infected mice explored the novel mouse for nearly oneand-a-half times longer than the uninfected mice (Fig. S4). Infection has previously been associated with social interaction, with $T$. gondii-infected rats exhibiting a longer duration of social interaction than controls (43). In phase 2 of the social approach test, which measures preference for social novelty, mice encountered the Stranger 1 mouse (the now-familiar mouse) as well as a novel mouse (Stranger 2) in the formerly empty cylinder. Both uninfected and infected mice investigated the novel stranger, but the infected mice investigated for a time period 1.5 times longer $(P=0.025)$, with a correlation, albeit weak, with DBH mRNA levels (Fig. S4).

\section{DISCUSSION}

In contrast to prior studies of the effect of T. gondii on neurotransmission in neurons, this study identified $\mathrm{DBH}$ gene regulation as the mechanism responsible for observed changes in norepinephrine and, in vitro, DA (9, 12-14, 19). Changes in GABA and glutamate metabolism in the CNS of chronically infected animals have previously been observed, with the distribution of the GABA-associated protein GAD67 altered (44) and GLT-1 expression in astrocytes reduced to half (45). The change in DBH expression observed in this study may provide a mechanism to explain, at least in part, diverse observations of CNS catecholamines with infection and behaviors associated with infection. In this study, downregulation of $\mathrm{DBH}$ was observed in the brains of $T$. gondii-infected males but not females (Fig. 3 and 4). In females, DBH expression 
A

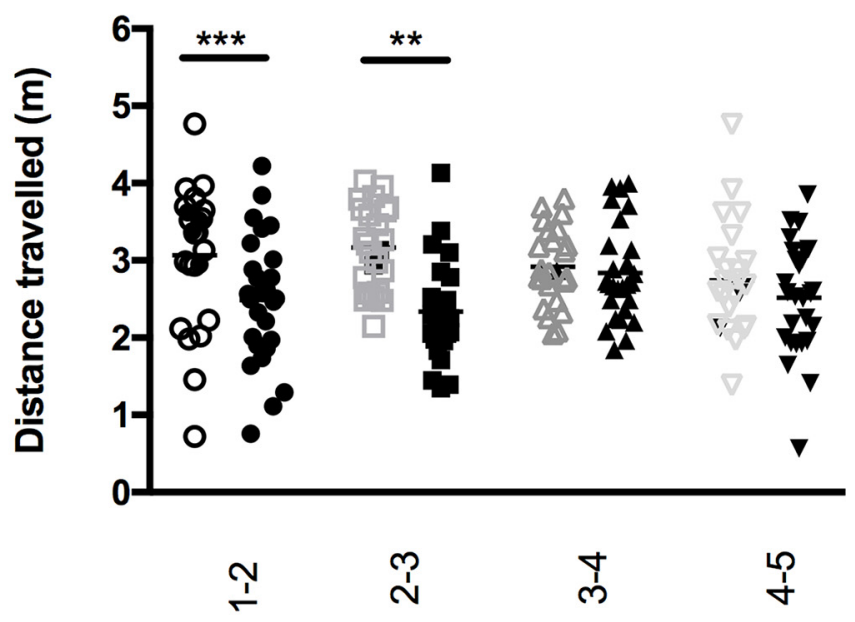

\section{Time (minutes)}

B

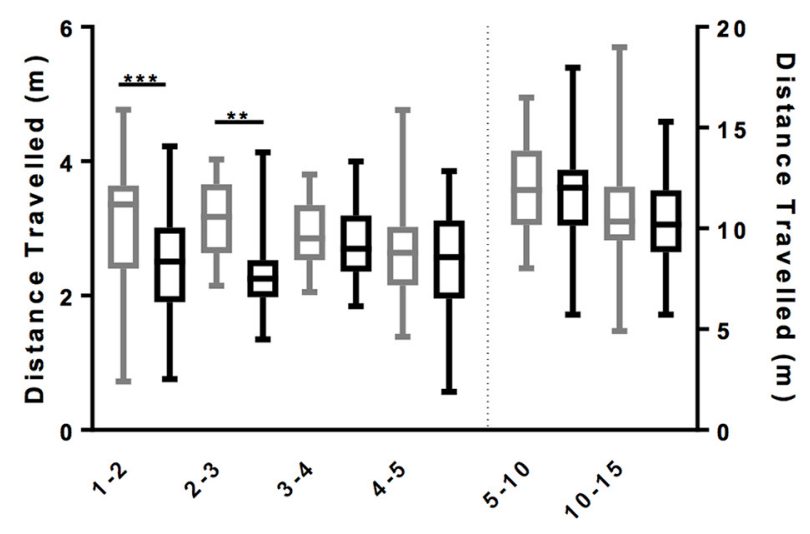

Time (minutes)

C

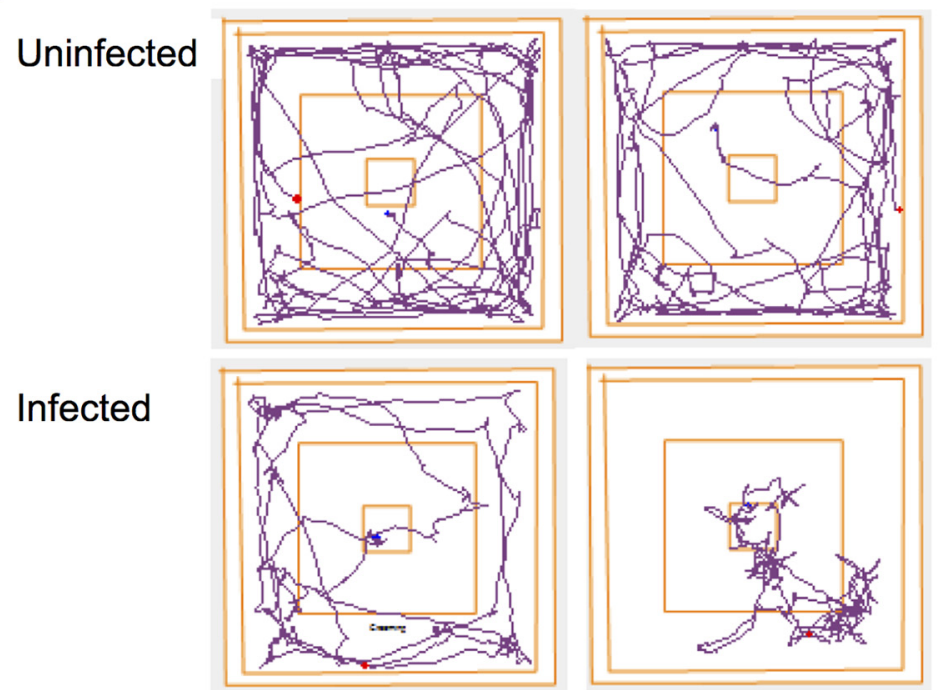

FIG 6 Locomotion and anxiety-related behaviors are altered in infected animals. (A) Mean ambulation of uninfected (gray) and infected (black) mice in the open field at single-minute time points. ${ }^{* *}, P=0.0015$; ${ }^{* * *}, P=0.000097 ; n=24$ uninfected and 27 infected mice. (B) Graph of distance moved for each mouse over the 15-min time course of the experiment plotted as a box plot, with whiskers representing minimum and maximum at single-minute time points followed by 5 -min time points. ${ }^{* *}, P=0.0015 ;{ }^{* * *}$, $P=0.000097$. (C) Tracking in the open field for representative uninfected (top) and infected (bottom) mice from 0 to $180 \mathrm{~s}$ in the trial. 
correlated with estrogen levels regardless of infection status (Fig. 4). Sex-specific downregulation of DBH may provide some insight into sex differences in behavioral changes with infection.

The downregulation of DBH expression provides an explanation for the observed decreases in NE in infected brains without a significant increase in DA in brain tissue observed in this and some prior studies (Fig. 1). This observation is not surprising given the small proportion of noradrenergic relative to dopaminergic neurons in the brain. Combined with the more severe pathology of $T$. gondii infection in mice with dysfunctional neurons, the small proportion of noradrenergic neurons provides a possible explanation for why this and other studies did not detect changes in total brain DA levels with infection $(12,16,24,29,46)$. In vitro, the downregulation of DBH found in this study can account, at least in part, for increased DA levels observed in infected PC12 cells observed in earlier studies $(9,19)$. In those studies, the amount of DA increased with infection while levels of the enzymes in synthesis, tyrosine hydroxylase and dopa decarboxylase (involved in dopamine synthesis), were unchanged, although dopa decarboxylase could be detected in the parasitophorous vacuole. T. gondii contains two paralogous genes that encode an aromatic amino acid hydroxylase (TgAAAH), with tyrosine and phenylalanine hydroxylase activities, that is secreted from the parasites into the parasitophorous vacuole (47). The gene products have been found to be involved in oocyst development, as proposed at their original discovery $(47,48)$. The effects of disruption of one of the two paralogs on catecholamine neurotransmission remain inconclusive; hence, collaborative experiments using the recently developed double knockout mutants lacking both genes are ongoing (48).

Noradrenergic neurons are principally located in the locus coeruleus (LC) in the brain and project to the thalamus, hippocampus, and the frontal and entorhinal cortices (49); efferent noradrenergic neurons originating in the LC were recently found to release DA in the dorsal hippocampus, thereby modulating a wide range of behaviors $(50,51)$. T. gondii cysts have been observed in these brain regions $(52,53)$. In this study, changes were observed in noradrenaline-related behaviors of arousal and social interactions (Fig. 6; see also the supplemental material). Previously, downregulation of the noradrenergic system has been observed to change social behavior, with $\mathrm{Dbh}^{-1-}$ knockout mice displaying increased sociability with lower aggression and social memory as well as reduced anxiety (35). Chronic T. gondii infection has also been found to impair long-term fear memory, a process that NE enhances $(12,54)$. Although one could attempt to reverse the parasite-induced effects on noradrenaline-related behaviors with noradrenergic inhibitors, antipsychotic drugs have antiparasitic effects $(24,55,56)$, and L-threo-3,4-dihydroxyphenylserine cannot be used because dopa decarboxylase, required for activation, is altered by $T$. gondii infection $(9,57)$.

There is a link between NE levels, T. gondii infection, and movement and coordination of the host. Both $\mathrm{Dbh} \mathrm{h}^{-1-}$ knockout in mice and noradrenergic neuron loss in the LC (in rats) lead to motor impairments and development of dyskinesia $(58,59)$. Further, mice lacking NE are susceptible to seizures $(60,61)$. Chronic infection with $T$. gondii in mice has also been associated with coordination difficulties (62), and loss of coordination is a common symptom of human toxoplasmosis. Severe toxoplasmosis can cause seizures, with documented cases of patients exhibiting Parkinsonian traits, such as bradykinesia $(63,64)$. Effects of altered GABA metabolism with $T$. gondii infection (observed in an earlier study) in promoting seizures would be compounded by a lack of anticonvulsant effect promulgated by NE (44).

DBH gene expression correlated with the intensity of infection, but the small number of neurons that are infected in vivo is difficult to reconcile with the large decrease in DBH expression (65). This global effect during in vivo infection is similar to that observed for GAD67 (glutamic acid decarboxylase) distribution in the brains of $T$. gondii-infected mice (44). The neuroimmune response may be involved, although DBH was downregulated in infected PC12 cells in vitro. Global changes could be mediated by injection of parasite proteins into cells without infecting the cells, as has been 
observed with neurons in infected mice $(7,66)$. The mechanism responsible for the global changes is the subject of ongoing studies.

In summary, infection of the CNS influences brain neurophysiology with $T$. gondii infection, decreasing NE levels through downregulating $\mathrm{DBH}$ gene expression. The regulation of $\mathrm{DBH}$ by estrogen may explain sex-specific effects of infection, as indeed $\mathrm{DBH}$ was not downregulated in infected females. Downregulation of $\mathrm{DBH}$, while suppressing $\mathrm{NE}$, can elevate $\mathrm{DA}$ in the same neurons. The consequential effects on neurological signaling of these alterations will be the subject of future studies, as they depend upon the location of the noradrenergic neurons and dopamine receptors. The mechanism(s) whereby the parasite downregulates DBH expression needs clarification. This may be via a parasite mechanism similar to that of $T$. gondii ROP18 altering JAK/STAT signaling pathways or via the regulation of vasopressin receptor by epigenetic changes $(67,68)$. The neurophysiological changes observed may provide insights into the mechanisms responsible for behavioral effects of T. gondii infection (69).

\section{MATERIALS AND METHODS}

Ethics. All procedures were approved by the University of Leeds Animal Ethical and Welfare Review Board and performed under United Kingdom Home Office Project and Personal Licenses, in accordance with the Animals (Scientific Procedures) Act, 1986. Rat brain sections were from infections conducted at the School of Public Health, Imperial College London (ICL), and procedures were approved by the ICL Animal Care and Use Committee and followed the same Home Office, HSE, regulations and guidelines. Considerations of replacement, reduction, and refinement were taken in the use of animals for research.

Rodent and rodent infections. The $(\mathrm{BALB} / \mathrm{CAnNCrl} \times \mathrm{C} 57 \mathrm{BL} / 6 \mathrm{NCrl}) \mathrm{F}_{1}$ mice used in this study were bred by crossing $\mathrm{C} 57 \mathrm{BL} / 6 \mathrm{NCrl}$ males to BALB/CAnNCrl females (Charles River Laboratories). The C57BL/6 inbred strain has been used as the genetic background in prior behavioral studies of $D b h^{-1-}$ knockout mice, while the BALC/c inbred strain possesses genetic resistance to control T. gondii brain infection and develops a latent chronic infection (22). In pilot studies, purebred C57BL/6NCrl mice infected with $T$. gondii showed severe toxoplasmic encephalitis.

Mice were housed five of the same sex per cage, with ad libitum access to food pellets and water. Mice were checked for health changes daily, and their weight was measured weekly. Any mouse showing severe illness or significant weight loss (25\%) was promptly culled. Mice were grouped according to treatment. Mice were infected by intraperitoneal (i.p.) injection with T. gondii type II strain Prugniaud in sterile phosphate-buffered saline (PBS) at 6 to 14 weeks of age. Infection was monitored by the direct agglutination test (bioMérieux) to detect Toxoplasma antibodies, by following the manufacturer's instructions, in sera from collected blood samples. Brains were harvested from euthanized animals and snap-frozen. Cryosectioned slices were used for RNA isolation as described for rats below.

Rat samples were from Lister Hooded rats (Harlan UK Ltd.), males and females housed separately and provided food and water ad libitum, that were infected at approximately 3 months of age via i.p. injection of $1 \times 10^{6}$ tachyzoites in sterile PBS. Uninfected control rats were i.p. injected with sterile PBS and sacrificed 5 to 6 months postinfection, with brains quick-frozen for cryosectioning. Sagittal slices were processed for RNA by dissolution with TRIzol (Thermo Fisher) for processing by following the manufacturer's instructions.

Growth of pathogens and cultured cells. The T. gondii Prugniaud strain was maintained in human foreskin fibroblast cell line Hs27 (ECACC 94041901) as previously described (47). Rat adrenal pheochromocytoma (PC12) cells (kind gift from C. Peers; ECACC 88022401) were maintained in RPMI medium (Invitrogen, Paisley, UK) supplemented with 10\% horse serum (Invitrogen), 5\% fetal bovine serum (FBS; Invitrogen), and $100 \mathrm{U} / \mathrm{ml}$ penicillin-streptomycin (Sigma, Poole, UK). PC12 cells were passaged by triturating, centrifuging at $800 \mathrm{rpm}$ for $10 \mathrm{~min}$ in a benchtop centrifuge, resuspending in fresh media, and incubating at $37^{\circ} \mathrm{C}$ in an atmosphere of $5 \% \mathrm{CO}_{2}$. The $\mathrm{BE}(2)-\mathrm{M} 17$ cells (kind gift from R. Wade-Martins, Oxford University) were maintained in a 1:1 ratio of $\mathrm{F} 12$ Hams to Opti-MEM (GIBCO, USA) medium supplemented with $10 \%$ horse serum (GIBCO, USA), 5\% FBS (GIBCO, USA), and $100 \mathrm{U} / \mathrm{ml}$ penicillinstreptomycin (Sigma, USA) and incubated in $5 \% \mathrm{CO}_{2}$ at $37^{\circ} \mathrm{C}$.

For the induction of parasite conversion to bradyzoite forms, free released tachyzoites were incubated at $37^{\circ} \mathrm{C}$ in RPMI supplemented with $1 \%$ FBS (pH 8.2) for 16 to $18 \mathrm{~h}$ in ambient air and then diluted with Dulbecco's modified Eagle's medium (Invitrogen), isolated by centrifugation, and suspended in RPMI ( $\mathrm{pH}$ 7.4) containing horse serum, FBS, and penicillin-streptomycin, as previously described (19). This method was developed because catecholamine-producing cells were found to be sensitive to $\mathrm{pH}$ changes, severely reducing their production of catecholamines. The parasite number was determined by microscopy, and an equal number of treated tachyzoites to cells was used for infections unless otherwise stated. The viability and differentiation of parasites in PC12 and BE(2)-M17 cultures were monitored by RT-qPCR (as described below) with T. gondii gene markers for GAPDH, tachyzoites (SAG1), and bradyzoites (SAG4 and BAG1) (see Fig. S5 in the supplemental material).

For HCMV studies, cells were infected with wild-type Merlin HCMV strain for $1 \mathrm{~h}$ and then washed and incubated with fresh media. RNA was harvested at the times shown. Cells were confirmed to be permissive for HCMV by IE antigen staining, which demonstrated susceptibility to infection similar to that of the neuronal cell line U-373, an established permissive HCMV cell line. 
Transcriptome analysis. A transcriptome screen was conducted to identifiy genes that are potentially differentially expressed with infection. PC12 cells were cultured in poly-D-lysine-coated 6-well plates (Sigma). Following $24 \mathrm{~h}$ of incubation, $6 \times 10^{4}$ cells were changed to medium with $1 \%$ horse serum, $0.5 \%$ FBS. After a further $24 \mathrm{~h}, 100 \mathrm{ng} / \mathrm{ml}$ of nerve growth factor (NGF; Sigma) was added. The addition of NGF was repeated once every $24 \mathrm{~h}$ throughout the length of the experiment. Control experiments found no effect of NGF on growth or bradyzoite conversion of T. gondii (data not shown). After $72 \mathrm{~h}$ from the initial addition of NGF, dendritic extensions were visible from differentiated cells. At this point, induced Prugniaud tachyzoites were transferred to each well, maintaining a parasite density of $2.5 \times 10^{4} \mathrm{cell} / \mathrm{s} / \mathrm{ml}$. Cells were harvested immediately following infection (day 0 ) and after 3 and 6 days of infection for RNA extraction. The cultures were monitored daily by light microscopy. At day 6 of infection, the parasitemia level was $60 \%$ to $70 \%$, with little observable cell lysis (data not shown).

Cells were detached from the surfaces by manual removal with a scraper, and several parallel biological repeats were pooled. The suspended cells were pelleted by centrifugation at $800 \times g$ for 10 min and lysed with TRI Reagent solution (Invitrogen), followed by centrifugation at $12,000 \times g$ for 10 min at $4^{\circ} \mathrm{C}$. RNA was purified by following the manufacturer's instructions. RNA samples were stored at $-80^{\circ} \mathrm{C}$. mRNA was enriched using a Poly(A)Purist MAG kit (Ambion), followed by further enrichment using RiboMinus (Ambion), by following the manufacturer's instructions. After quality control analysis using a Bioanalyzer (Agilent), cDNA libraries were prepared from RNA using the Epicentre ScriptSeq v2 RNA-Seq library preparation kit and sequenced using the Illumina HiSeq 2000 at the University of Liverpool Centre for Genomic Research. Two libraries for each pool of biological repeats of infected and uninfected cells at the three time points were sequenced. RNA sequencing generated 353 million paired-end reads, with a total of 26,405 Rattus norvegicus genes identified.

The Illumina reads from the RNA sequencing were separately mapped to Rattus norvegicus and Toxoplasma gondii reference genomes using TopHat 2.0.8b (70). Differential expression analyses were performed using the edgeR package, version 3.0.4 (71), for the reads aligned to the rat genome. The reads that aligned with the $T$. gondii genome were analyzed for bradyzoite markers (Table S1). A gene was considered differentially expressed (DE) if the fold change was greater than two $\left[-1>\log _{2}\right.$ (fold change) $>1$ ] and the false discovery rate was $<0.01$ (maximum false-positive genes are $1 \%$ of the genes). The resultant 488 genes form a set of DE genes that exhibit down- or upregulation. The enriched GO (biological process) and KEGG pathway terms for up- and downregulated gene sets were computed using DAVID and are tabulated in Table S2 (72).

Reverse transcriptase PCR and qPCR. For RT-qPCR assays, cultures of $2.5 \times 10^{4} \mathrm{PC12}$ or BE(2)-M17 cells in multiwell plates were infected with induced $T$. gondii tachyzoites. Cells were recovered by centrifugation, and the cell pellet was frozen $\left(-80^{\circ} \mathrm{C}\right)$ for RNA extraction and high-performance liquid chromatography-electrochemical detection (HPLC-ED) analysis.

RNA was purified using Direct-Zol (Zymo) and reverse transcribed to CDNA using a Maxima firststrand CDNA synthesis kit (Thermo Fisher) by following the manufacturer's instructions. RT-qPCR was performed on RNA, as described previously, using SYBR green real-time PCR master mix (Thermo Fisher) using rat GAPDH primers (Qiagen), DDC primers 5'-CGGAGAAGAGGGAAGGAGATGGT-3' and 5'-GCCGT GGGGAAGTAAGCGAAG-3', TH primers 5'-CCCAAAGTCTCCATCCCCTTC- $3^{\prime}$ and $5^{\prime}$-GGTTGAGAAGCAGTGT TGGGA-3', MoaA primers 5'-GTGTGGGAGGCAGGACTTAC-3' and 5'-CTGGCGAATCACCCTTCC-3', PAH primers 5'-CTGGGGAACGGTGTTCAGGA-3' and 5'-TCTTCACGGAAACCGCAGTA-3', DRD1 primers 5'-CAA GTCCCCGGAAGTGTG-3' and 5'-CAGGTGTCGAAACCGGATG-3', DBH primers 5'-CCACAATCCGGAATAT A-3' and $5^{\prime}$-GATGCCTGCCTCATTGGG-3', and ESR1 primers $5^{\prime}$-CTACGCTGTACGCGACAC- $3^{\prime}$ and $5^{\prime}$-CCAT TCTGGCGTCGATTG-3'.

HPLC for monoamines. The catecholamines DA and NE were measured by HPLC-ED, adapting a previously published method (19). Briefly, cultures were harvested by scraping cells and recovered by centrifugation, and an aliquot was taken for cell counting and normalization. The remaining cells were recovered again and resuspended in $350 \mu \mathrm{l}$ of perchloric acid, followed by sonication. The mixture was centrifuged at $14,000 \mathrm{rpm}$ for $15 \mathrm{~min}$ at $4^{\circ} \mathrm{C}$ to remove particulates, and an aliquot was taken for HPLC analysis. NE was detected at $4.5 \mathrm{~min}$ and DA at $8 \mathrm{~min}$ (flow rate, $0.4 \mathrm{ml} / \mathrm{min}$ ) by HPLC-ED on a Dionex UltiMate 3000 system (Thermo Fisher).

Mouse behavioral testing. After establishment of chronic infection ( 4 to 5 weeks), mice were tested in a battery of behavioral tests in the following order, with an interval of 2 days between each test: open field, marble burying, and social approach. Prior to testing, mice were habituated to handling for $5 \mathrm{~min}$ per day for 7 days. Ethanol (70\%) was used to clean the arena between mice. The arena was left to dry for 3 to $4 \mathrm{~min}$ before commencing with the next subject.

Open field test. The open field arena had an internal diameter of 40 by $40 \mathrm{~cm}$ with a semitransparent Perspex wall. The arena floor was white plastic. To prevent the mice from seeing the surrounding room, a cylinder of white card was placed around the arena $30 \mathrm{~cm}$ away from its walls. The ambulation of the mice was recorded using a tripod-mounted webcam above the center of the arena.

Mice were individually placed at the center of the arena facing the same wall. Readings began after the initial $60 \mathrm{~s}$ because of disturbances involved in the experimenter removing mice from their cages, placing them in the open field, and withdrawing to a computer to manually start the recording. Distance travelled was then recorded for $14 \mathrm{~min}$, without interruptions or intervals, using AnyMaze tracking software (Stoelting Co.).

Social approach. Sociability was assessed using a three-chambered arena $(60$ by $40 \mathrm{~cm})$ that had two openings $(7$ by $8 \mathrm{~cm}$ ) to allow the mouse access to the left and right chambers from the central chamber (each chamber measured 40 by $20 \mathrm{~cm}$ ). The test involved using two unfamiliar mice that had been habituated to stainless steel cylinders (width, $10 \mathrm{~cm}$; height, $10.5 \mathrm{~cm}$ ) prior to the test. The cylinders were 
made of vertical metal bars separated by $9 \mathrm{~mm}$, which allowed air exchange and increased the possibility of contact between the test and stranger mice.

Following a previously published protocol (41), a test mouse was placed into the central chamber of the three-chambered arena. The habituation stage was carried out for $15 \mathrm{~min}$; at the end of this time, the openings to the side chambers were blocked by guillotine doors. A cylinder was placed in both the right and the left chamber. A stranger mouse (Stranger 1, a young male C57BL/6NCrl) was placed in the cylinder in either the left or right chamber (balanced between treatment groups). Following this, the doors were removed and phase 1 was initiated, lasting $10 \mathrm{~min}$.

Social approach was scored when the test mouse's nose poked through the bars of either the cylinder containing Stranger 1 or the empty cylinder. At the end of phase 1, the test mouse was placed in the central chamber and the doors were shut. A new, unfamiliar mouse (Stranger 2) was placed in the formerly empty cylinder. At this point, phase 2 was initiated, again lasting for $10 \mathrm{~min}$. Social approach was scored when the test mouse's nose poked through the bars of either the cylinder containing stranger 1 or the cylinder containing stranger 2 . The cylinders and floor were then wiped clean with $70 \%$ ethanol. The experimenter wore nitrile gloves throughout the procedure.

Statistical analysis. GraphPad Prism (version 7) was used for statistical analyses. Unless otherwise stated, data sets were compared using Student's $t$ test with $P$ values calculated. All data are plotted as means \pm standard errors of the means (SEM).

\section{SUPPLEMENTAL MATERIAL}

Supplemental material for this article may be found at https://doi.org/10.1128/IAI .00789-18.

SUPPLEMENTAL FILE 1, PDF file, $0.3 \mathrm{MB}$.

\section{ACKNOWLEDGMENTS}

We have no competing financial interests to declare.

The main manuscript text was written by I.A., E.T., and G.A.M., with input from all authors. Experiments were performed and figures and tables prepared by I.A., E.T., M.A., G.B., and M.S.V. I.A., G.A.M., and J.W. contributed to the conceptualization and experimental planning.

M.R. is supported by MRC Fellowship G:0900466. The Stanley Medical Research Institute supported early components of this study.

\section{REFERENCES}

1. Webster JP, Brunton CF, MacDonald DW. 1994. Effect of Toxoplasma gondii upon neophobic behaviour in wild brown rats, Rattus norvegicus. Parasitology 109:37-43. https://doi.org/10.1017/S003118200007774X.

2. Vyas A, Kim S-K, Giacomini N, Boothroyd JC, Sapolsky RM. 2007. Behavioral changes induced by Toxoplasma infection of rodents are highly specific to aversion of cat odors. Proc Natl Acad Sci U S A 104: 6442-6447. https://doi.org/10.1073/pnas.0608310104.

3. Bouwknegt M, Devleesschauwer B, Graham H, Robertson LJ, van der Giessen JW, The Euro-Fbp Workshop Participants. 2018. Prioritisation of food-borne parasites in Europe, 2016. Euro Surveill 23:17-00161.

4. Melzer TC, Cranston HJ, Weiss LM, Halonen SK. 2010. Host cell preference of Toxoplasma gondii cysts in murine brain: a confocal study. J Neuroparasitol 1:1-6. https://doi.org/10.4303/jnp/N100505.

5. Wastling J, Heap S, Ferguson D. 2000. Toxoplasma gondii-keeping our guests under control. Biologist (Lond) 47:234-238.

6. Ferguson DJ, Hutchison WM. 1987. An ultrastructural study of the early development and tissue cyst formation of Toxoplasma gondii in the brains of mice. Parasitol Res 73:483-491. https://doi.org/10.1007/ BF00535321.

7. Cabral CM, Tuladhar S, Dietrich HK, Nguyen E, MacDonald WR, Trivedi T, Devineni A, Koshy AA. 2016. Neurons are the primary target cell for the brain-tropic intracellular parasite Toxoplasma gondii. PLoS Pathog 12: e1005447. https://doi.org/10.1371/journal.ppat.1005447.

8. Syn G, Anderson D, Blackwell JM, Jamieson SE. 2018. Epigenetic dysregulation of host gene expression in Toxoplasma infection with specific reference to dopamine and amyloid pathways. Infect Genet Evol 65: 159-162. https://doi.org/10.1016/j.meegid.2018.07.034.

9. Martin HL, Alsaady I, Howell G, Prandovszky E, Peers C, Robinson P, McConkey GA. 2015. Effect of parasitic infection on dopamine biosynthesis in dopaminergic cells. Neuroscience 306:50-62. https://doi.org/ 10.1016/j.neuroscience.2015.08.005.

10. Webster JP, Lamberton PHL, Donnelly CA, Torrey EF. 2006. Parasites as causative agents of human affective disorders? The impact of anti- psychotic, mood-stabilizer and anti-parasite medication on Toxoplasma gondii's ability to alter host behaviour. Proc Biol Sci 273:1023-1030. https://doi.org/10.1098/rspb.2005.3413.

11. Skallová A, Kodym P, Frynta D, Flegr J. 2006. The role of dopamine in Toxoplasma-induced behavioural alterations in mice: an ethological and ethopharmacological study. Parasitology 133:525-535. https://doi.org/ $10.1017 /$ S0031182006000886.

12. Ihara F, Nishimura M, Muroi $Y$, Mahmoud ME, Yokoyama N, Nagamune K, Nishikawa Y. 2016. Toxoplasma gondii infection in mice impairs long-term fear memory consolidation through dysfunction of the cortex and amygdala. Infect Immun 84:2861-2870. https://doi.org/10.1128/IAI .00217-16

13. Xiao J, Li Y, Prandovszky E, Kannan G, Viscidi RP, Pletnikov MV, Yolken $\mathrm{RH}$. 2016. Behavioral abnormalities in a mouse model of chronic toxoplasmosis are associated with MAG1 antibody levels and cyst burden. PLoS Negl Trop Dis 10:e0004674. https://doi.org/10.1371/journal.pntd .0004674 .

14. Stibbs HH. 1985. Changes in brain concentrations of catecholamines and indoleamines in Toxoplasma gondii infected mice. Ann Trop Med Parasitol 79:153-157. https://doi.org/10.1080/00034983.1985.11811902.

15. Luo XM, Yuan SN, Guan XT, Xie X, Shao F, Wang WW. 2014. Juvenile stress affects anxiety-like behavior and limbic monoamines in adult rats. Physiol Behav 135:7-16. https://doi.org/10.1016/j.physbeh.2014.05.035.

16. Gatkowska J, Wieczorek M, Dziadek B, Dzitko K, Dlugonska H. 2013. Sex-dependent neurotransmitter level changes in brains of Toxoplasma gondii-infected mice. Exp Parasitol 133:1-7. https://doi.org/10.1016/j .exppara.2012.10.005.

17. Strobl JS, Goodwin DG, Rzigalinski BA, Lindsay DS. 2012. Dopamine stimulates propagation of Toxoplasma gondii tachyzoites in human fibroblast and primary neonatal rat astrocyte cell cultures. J Parasitol 98:1296-1299. https://doi.org/10.1645/GE-2760.1.

18. Tan D, Soh LJT, Lim LW, Daniel TCW, Zhang X, Vyas A. 2015. Infection of male rats with Toxoplasma gondii results in enhanced delay aversion 
and neural changes in the nucleus accumbens core. Proc Biol Sci 282: 20150042. https://doi.org/10.1098/rspb.2015.0042.

19. Prandovszky E, Gaskell E, Martin H, Dubey JP, Webster JP, McConkey GA. 2011. The neurotropic parasite Toxoplasma gondii increases dopamine metabolism. PLoS One 6:e23866. https://doi.org/10.1371/journal.pone .0023866 .

20. Popova NK, Skrinskaya YA, Amstislavskaya TG, Vishnivetskaya GB, Seif I, de Meier E. 2001. Behavioral characteristics of mice with genetic knockout of monoamine oxidase type A. Neurosci Behav Physiol 31:597-602. https://doi.org/10.1023/A:1012364910091.

21. Bourdélat-Parks BN, Anderson GM, Donaldson ZR, Weiss JM, Bonsall RW Emery MS, Liles LC, Weinshenker D. 2005. Effects of dopamine $\beta$-hydroxylase genotype and disulfiram inhibition on catecholamine homeostasis in mice. Psychopharmacology (Berl) 183:72-80. https://doi .org/10.1007/s00213-005-0139-8.

22. Suzuki Y, Joh K, Orellana MA, Conley FK, Remington JS. 1991. A gene(s) within the $\mathrm{H}-2 \mathrm{D}$ region determines the development of toxoplasmic encephalitis in mice. Immunology 74:732-739.

23. Webster JP, Kaushik M, Bristow GC, McConkey GA. 2013. Toxoplasma gondii infection, from predation to schizophrenia: can animal behaviour help us understand human behaviour? J Exp Biol 216:99-112. https:// doi.org/10.1242/jeb.074716.

24. Goodwin DG, Strobl JS, Lindsay DS. 2011. Evaluation of five antischizophrenic agents against Toxoplasma gondii in human cell cultures. J Parasitol 97:148-151. https://doi.org/10.1645/GE-2536.1.

25. McConkey GA, Peers C, Prandovszky E. 2015. Reproducing increased dopamine with infection to evaluate the role of parasite-encoded tyrosine hydroxylase activity. Infect Immun 83:3334-3335. https://doi.org/ 10.1128/IAI.00605-15.

26. Taylor SC, Roberts ML, Peers C. 1999. Acid-evoked quantal catecholamine secretion from rat phaeochromocytoma cells and its interaction with hypoxia-evoked secretion. J Physiol 519:765-774. https://doi.org/ 10.1111/j.1469-7793.1999.0765n.x.

27. Tanaka S, Nishimura M, Ihara F, Yamagishi J, Suzuki Y, Nishikawa Y. 2013. Transcriptome analysis of mouse brain infected with Toxoplasma gondii. Infect Immun 81:3609-3619. https://doi.org/10.1128/IAl.00439-13.

28. Pittman KJ, Aliota MT, Knoll LJ. 2014. Dual transcriptional profiling of mice and Toxoplasma gondii during acute and chronic infection. BMC Genomics 15:806. https://doi.org/10.1186/1471-2164-15-806.

29. Haroon F, Händel U, Angenstein F, Goldschmidt J, Kreutzmann $P$, Lison H, Fischer KD, Scheich H, Wetzel W, Schlüter D, Budinger E. 2012. Toxoplasma gondii actively inhibits neuronal function in chronically infected mice. PLoS One 7:e35516. https://doi.org/10.1371/journal.pone .0035516 .

30. Serova L, Rivkin M, Nakashima A, Sabban EL. 2002. Estradiol stimulates gene expression of norepinephrine biosynthetic enzymes in rat locus coeruleus. Neuroendocrinology 75:193-200. https://doi.org/10.1159/000048237.

31. Serova LI, Harris HA, Maharjan S, Sabban EL. 2010. Modulation of responses to stress by estradiol benzoate and selective estrogen receptor agonists. J Endocrinol 205:253-262. https://doi.org/10.1677/ JOE-10-0029.

32. Shughrue PJ, Bushnell CD, Dorsa DM. 1992. Estrogen receptor messenger ribonucleic acid in female rat brain during the estrous cycle: a comparison with ovariectomized females and intact males. Endocrinology 131:381-388. https://doi.org/10.1210/endo.131.1.1612018.

33. Xiao J, Kannan G, Jones-Brando L, Brannock C, Krasnova INN, Cadet JLL, Pletnikov M, Yolken RHH. 2012. Sex-specific changes in gene expression and behavior induced by chronic Toxoplasma infection in mice. Neuroscience 206:39-48. https://doi.org/10.1016/j.neuroscience.2011.12.051.

34. Golcu D, Gebre RZ, Sapolsky RM. 2014. Toxoplasma gondii influences aversive behaviors of female rats in an estrus cycle dependent manner. Physiol Behav 135:98-103. https://doi.org/10.1016/j.physbeh.2014.05.036.

35. Marino MD, Bourdélat-Parks BN, Cameron Liles L, Weinshenker D. 2005. Genetic reduction of noradrenergic function alters social memory and reduces aggression in mice. Behav Brain Res 161:197-203. https://doi .org/10.1016/j.bbr.2005.02.005.

36. Mitchell HA, Bogenpohl JW, Liles LC, Epstein MP, Bozyczko-Coyne D, Williams M, Weinshenker D. 2008. Behavioral responses of dopamine $\beta$-hydroxylase knockout mice to modafinil suggest a dual noradrenergicdopaminergic mechanism of action. Pharmacol Biochem Behav 91:217-222. https://doi.org/10.1016/j.pbb.2008.07.014.

37. Havlícek J, Gašová Z, Smith AP, Zvára K, Flegr J. 2001. Decrease of psychomotor performance in subjects with latent "asymptomatic" toxoplasmosis. Parasitology 122:515-520.
38. Eells JB, Varela-Stokes A, Guo-Ross SX, Kummari E, Smith HM, Cox E, Lindsay DS. 2015. Chronic toxoplasma gondii in nurr1-null heterozygous mice exacerbates elevated open field activity. PLoS One 10:e0119280. https://doi.org/10.1371/journal.pone.0119280.

39. Hay J, Hutchison WM, Aitken PP, Graham DI. 1983. The effect of congenital and adult-acquired Toxoplasma infections on activity and responsiveness to novel stimulation in mice. Ann Trop Med Parasitol 77:483-495. https://doi.org/10.1080/00034983.1983.11811741.

40. Gatkowska J, Wieczorek M, Dziadek B, Dzitko K, Dlugonska H. 2012. Behavioral changes in mice caused by Toxoplasma gondii invasion of brain. Parasitol Res 111:53-58. https://doi.org/10.1007/s00436-011-2800-y.

41. Clapcote SJ, Lipina TV, Millar JK, Mackie S, Christie S, Ogawa F, Lerch JP, Trimble K, Uchiyama M, Sakuraba Y, Kaneda H, Shiroishi T, Houslay MD, Henkelman RM, Sled JG, Gondo Y, Porteous DJ, Roder JCC. 2007. Behavioral phenotypes of Disc1 missense mutations in mice. Neuron 54: 387-402. https://doi.org/10.1016/j.neuron.2007.04.015.

42. Dachtler J, Ivorra JL, Rowland TE, Lever C, John Rodgers R, Clapcote SJ. 2015. Heterozygous deletion of $\alpha$-neurexin I or $\alpha$-neurexin II results in behaviors relevant to autism and schizophrenia. Behav Neurosci 129: 765-776. https://doi.org/10.1037/bne0000108.

43. Gonzalez LE, Rojnik B, Urrea F, Urdaneta H, Petrosino P, Colasante C, Pino S, Hernandez L. 2007. Toxoplasma gondii infection lower anxiety as measured in the plus-maze and social interaction tests in rats. A behavioral analysis. Behav Brain Res 177:70-79. https://doi.org/10.1016/j.bbr .2006.11.012.

44. Brooks JM, Carrillo GL, Su J, Lindsay DS, Fox MA, Blader IJ. 2015. Toxoplasma gondii infections alter GABAergic synapses and signaling in the central nervous system. mBio 6:e01428-15. https://doi.org/10.1128/ mBio.01428-15.

45. David CN, Frias ES, Szu Jl, Vieira PA, Hubbard JA, Lovelace J, Michael M, Worth D, McGovern KE, Ethell IM, Stanley BG, Korzus E, Fiacco TA, Binder DK, Wilson EH. 2016. GLT-1-dependent disruption of CNS glutamate homeostasis and neuronal function by the protozoan parasite Toxoplasma gondii. PLoS Pathog 12:e1005643. https://doi.org/10.1371/journal.ppat.1005643.

46. Parlog A, Harsan L-A, Zagrebelsky M, Weller M, von Elverfeldt D, Mawrin C, Korte M, Dunay IR. 2014. Chronic murine toxoplasmosis is defined by subtle changes in neuronal connectivity. Dis Model Mech 7:459-469. https://doi.org/10.1242/dmm.014183.

47. Gaskell EA, Smith JE, Pinney JW, Westhead DR, McConkey GA. 2009. A unique dual activity amino acid hydroxylase in Toxoplasma gondii. PLoS One 4:e4801. https://doi.org/10.1371/journal.pone.0004801.

48. Wang ZT, Verma SK, Dubey JP, Sibley LD. 2017. The aromatic amino acid hydroxylase genes $\mathrm{AAH} 1$ and $\mathrm{AAH} 2$ in Toxoplasma gondii contribute to transmission in the cat. PLoS Pathog 13:e1006272. https://doi.org/10 .1371/journal.ppat.1006272.

49. Freedman R, Foote SL, Bloom FE. 1975. Histochemical characterization of a neocortical projection of the nucleus locus coeruleus in the squirrel monkey. J Comp Neurol 164:209-231. https://doi.org/10.1002/cne .901640205 .

50. Smith CC, Greene RW. 2012. CNS dopamine transmission mediated by noradrenergic innervation. J Neurosci 32:6072-6080. https://doi.org/10 .1523/JNEUROSCI.6486-11.2012.

51. Kempadoo KA, Mosharov EV, Choi SJ, Sulzer D, Kandel ER. 2016. Dopamine release from the locus coeruleus to the dorsal hippocampus promotes spatial learning and memory. Proc Natl Acad Sci U S A 113:14835-14840. https://doi.org/10.1073/pnas.1616515114.

52. Berenreiterová $M$, Flegr J, Kuběna AA, Němec $P$. 2011. The distribution of Toxoplasma gondii cysts in the brain of a mouse with latent toxoplasmosis: implications for the behavioral manipulation hypothesis. PLoS One 6:e28925. https://doi.org/10.1371/journal.pone.0028925.

53. McConkey GA, Martin HL, Bristow GC, Webster JP. 2013. Toxoplasma gondii infection and behaviour-location, location, location? J Exp Biol 216:113-119. https://doi.org/10.1242/jeb.074153.

54. Kabitzke PA, Silva L, Wiedenmayer C. 2011. Norepinephrine mediates contextual fear learning and hippocampal PCREB in juvenile rats exposed to predator odor. Neurobiol Learn Mem 96:166-172. https://doi .org/10.1016/j.nlm.2011.04.003.

55. Jones-Brando L, Torrey EF, Yolken R. 2003. Drugs used in the treatment of schizophrenia and bipolar disorder inhibit the replication of Toxoplasma gondii. Schizophr Res 62:237-244. https://doi.org/10.1016/S0920 -9964(02)00357-2.

56. Fond G, Macgregor A, Tamouza R, Hamdani N, Meary A, Leboyer M, Dubremetz JF. 2014. Comparative analysis of anti-toxoplasmic activity of 
antipsychotic drugs and valproate. Eur Arch Psychiatry Clin Neurosci 264:179-183. https://doi.org/10.1007/s00406-013-0413-4.

57. Cryan JF, O'Leary OF, Jin S-H, Friedland JC, Ouyang M, Hirsch BR, Page ME, Dalvi A, Thomas SA, Lucki I. 2004. Norepinephrine-deficient mice lack responses to antidepressant drugs, including selective serotonin reuptake inhibitors. Proc Natl Acad Sci USA 101:8186-8191. https://doi .org/10.1073/pnas.0401080101.

58. Rommelfanger KS, Edwards GL, Freeman KG, Liles LC, Miller GW, Weinshenker D. 2007. Norepinephrine loss produces more profound motor deficits than MPTP treatment in mice. Proc Natl Acad Sci U S A 104: 13804-13809. https://doi.org/10.1073/pnas.0702753104.

59. Shin E, Rogers JT, Devoto P, Björklund A, Carta M. 2014. Noradrenaline neuron degeneration contributes to motor impairments and development of L-DOPA-induced dyskinesia in a rat model of Parkinson's disease. Exp Neurol 257:25-38. https://doi.org/10.1016/j.expneurol.2014.04 .011 .

60. Szot $P$, Weinshenker D, White SS, Robbins CA, Rust NC, Schwartzkroin PA, Palmiter RD. 1999. Norepinephrine-deficient mice have increased susceptibility to seizure-inducing stimuli. J Neurosci 19:10985-10992. https://doi.org/10.1523/JNEUROSCl.19-24-10985.1999.

61. Weinshenker D, Szot P, Miller NS, Palmiter RD. 2001. Alpha(1) and beta(2) adrenoreceptor agonists inhibit pentylenetetrazole-induced seizures in mice lacking norepinephrine. J Pharmacol Exp Ther 298:1042-1048.

62. Halonen SK, Weiss LM. 2013. Toxoplasmosis. Handb Clin Neurol 114: 125-145. https://doi.org/10.1016/B978-0-444-53490-3.00008-X.

63. Murakami T, Nakajima M, Nakamura T, Hara A, Uyama E, Mita S, Matsushita S, Uchino M. 2000. Parkinsonian symptoms as an initial manifestation in a Japanese patient with acquired immunodeficiency syndrome and Toxoplasma infection. Intern Med 39:1111-1114. https://doi.org/10 .2169/internalmedicine.39.1111.

64. Nath A, Hobson DE, Russell A. 1993. Movement disorders with cerebral toxoplasmosis and AIDS. Mov Disord 8:107-112. https://doi.org/10.1002/ mds.870080119.

65. Dubey JP, Ferreira LR, Alsaad M, Verma SK, Alves DA, Holland GN, McConkey GA. 2016. Experimental toxoplasmosis in rats induced orally with eleven strains of Toxoplasma gondii of seven genotypes: tissue tropism, tissue cyst size, neural lesions, tissue cyst rupture without reactivation, and ocular lesions. PLoS One 11:e0156255. https://doi.org/ 10.1371/journal.pone.0156255.

66. Koshy AA, Dietrich HK, Christian DA, Melehani JH, Shastri AJ, Hunter CA, Boothroyd JC. 2012. Toxoplasma co-opts host cells it does not invade. PLoS Pathog 8:e1002825. https://doi.org/10.1371/journal.ppat.1002825.

67. Schneider AG, Abi Abdallah DS, Butcher BA, Denkers EY. 2013. Toxoplasma gondii triggers phosphorylation and nuclear translocation of dendritic cell STAT1 while simultaneously blocking IFN $\gamma$-induced STAT1 transcriptional activity. PLoS One 8:e60215. https://doi.org/10.1371/ journal.pone.0060215.

68. Hari Dass SA, Vyas A. 2014. Toxoplasma gondii infection reduces predator aversion in rats through epigenetic modulation in the host medial amygdala. Mol Ecol 23:6114-6122. https://doi.org/10.1111/mec.12888.

69. Flegr J. 2007. Effects of Toxoplasma on human behavior. Schizophr Bull 33:757-760. https://doi.org/10.1093/schbul/sbl074.

70. Trapnell C, Pachter L, Salzberg SL. 2009. TopHat: discovering splice junctions with RNA-Seq. Bioinformatics 25:1105-1111. https://doi.org/10 .1093/bioinformatics/btp120.

71. Robinson MD, McCarthy DJ, Smyth GK. 2010. edgeR: a Bioconductor package for differential expression analysis of digital gene expression data. Bioinformatics 26:139-140. https://doi.org/10.1093/bioinformatics/btp616.

72. Huang DW, Sherman BT, Zheng X, Yang J, Imamichi T, Stephens R, Lempicki RA. 2009. Extracting biological meaning from large gene lists with DAVID. Curr Protoc Bioinformatics 13:Unit 13.11.

73. Ngô HM, Zhou Y, Lorenzi H, Wang K, Kim TK, Zhou Y, Bissati KE, Mui E, Fraczek L, Rajagopala SV, Roberts CW, Henriquez FL, Montpetit A, Blackwell JM, Jamieson SE, Wheeler K, Begeman IJ, Naranjo-Galvis C, AllieyRodriguez N, Davis RG, Soroceanu L, Cobbs C, Steindler DA, Boyer K, Noble AG, Swisher CN, Heydemann PT, Rabiah P, Withers S, Soteropoulos P, Hood L, McLeod R. 2017. Toxoplasma modulates signature pathways of human epilepsy, neurodegeneration \& cancer. Sci Rep 7:11496. https://doi.org/10.1038/s41598-017-10675-6. 